\title{
The life span of erythrocytes in iron-deficiency anaemia
}

\author{
I. J. TEMPERLEY AND A. A. SHARP \\ From the Department of Haematology, Radcliffe Infirmary, Oxford
}

SYNOPSIS Red cells, derived from 13 patients with iron-deficiency anaemia, were found to have normal life span in the patients' own circulations and those of normal volunteers.

The life span of iron-deficient red cells in circulating blood is assumed by most haematologists to be normal, yet the wide variety of shape and size adopted by iron-deficient red cells suggested that this might not be so.

Using the Ashby technique for measuring red cell survival, Brown, Hayward, Powell, and Witts (1944) have shown that normal red cells survive for a normal period when transfused into an iron-deficient patient, and iron-deficient red cells survive normally when transfused into a normal person (Kaplan and Zuelzer, 1950).

However, Rasch, Cotton, Griggs, and Harris (1958), using ${ }^{51} \mathrm{Cr}$-tagged iron-deficient red cells, reported a decreased red cell survival in 14 irondeficient infants and, using the same method, Verloop, Van der Wolk, and Heier (1960) found a shortened life span in five out of six patients with iron-deficiency anaemia.

In view of these results, a further investigation of this problem was undertaken and the survival of iron-deficient red cells was studied, using the blood from 13 iron-deficiency patients.

\section{METHODS}

MEASUREMENT OF LIFE SPAN OF ERYTHROCYTES $\left({ }^{51} \mathrm{Cr}\right)$ The method of labelling the erythrocytes was that described by Veall and Vetter (1958). The blood was added to an anticoagulant mixture in a universal container, 15 to $20 \mathrm{ml}$. of blood to $3 \mathrm{ml}$. of acid citrate dextrose. After centrifuging the supernatant plasma was removed and 2 to $3 \mathrm{ml}$. of this was added to $100 \mathrm{ml}$. sterile saline; the remainder of the plasma was discarded. Then $100 \mu \mathrm{c} .{ }^{51} \mathrm{Cr}$ was added to the packed cells. The red cells were left at room temperature for $\mathbf{3 0}$ minutes before washing twice in the plasma-saline. The washed red cells were finally resuspended in plasma-saline to make a total volume of 18 to $20 \mathrm{ml}$.; the ${ }^{51} \mathrm{Cr}$-labelled red cells were injected intravenously, and the $100 \%$ sample was taken at 15

Received for publication 29 January 1962. minutes. One more sample was taken at 24 hours, an $\$$ the activity of all samples was estimated on an EkcQ pillar scintillation counter. The results are expressed as the percentage ${ }^{51} \mathrm{Cr}$ activity and not corrected foE elution.

ESTIMATION OF BLOOD LOSS IN FAECES Faeces were colø̋ lected for periods of 10 to 14 days and pooled into cartons which fitted the well of a plastic phosphor counter The radioactivity of the faeces was measured and com乏 pared with the activity of appropriate standards, prepare from the patients' own blood in similar cartons. Frond these standards the radioactivity/volume of faeces wasD related to millilitres of the patients' blood.

ESTIMATION OF SERUM IRON Two methods were used (Bothwell and Mallet, 1955; Ramsay, 1954).

CLINICAL MATERIAL

The 13 patients were considered to have uncomplicated iron-deficiency anaemia. Patients with disseminated malignancy, renal and hepatic failure, infection, associo ated vitamin $\mathbf{B}_{12}$, or folic acid deficiency states were excluded. Three of the patients selected for autotranso fusion were bleeding from the gastro-intestinal tract and continued to do so throughout the study. The criteria used to substantiate the diagnosis of iron-deficiency. anaemia were as follows:

A haemoglobin estimation of less than $11.5 \mathrm{~g} / 100 \mathrm{ml}$ in women and $13.5 \mathrm{~g} . / 100 \mathrm{ml}$. in men (Dacie, 1956); mean corpuscular haemoglobin concentration of lessw than $32 \%$; a typical blood film of iron-deficiency anaemia; a serum iron level of less than $60 \mu \mathrm{g} . / 100 \mathrm{ml}$. a good response to iron therapy.

Table I represents the data collected to satisfy the above criteria. All the blood films showed the changes found in iron deficiency-anisocytosis, poikilocytosis, and hypochromia. Because of the uniformity of these findingso they are not included in Table I. A serum bilirubin estimation was carried out in each case and the highesto level was $0.3 \mathrm{mg} . / 100 \mathrm{ml}$. Bogomolow's screening test for urobilinogen in the urine was negative in each case.

The survival of iron-deficient red cells from 10 patientso 
TABLE I

CLINICAL FINDINGS IN CASES OF IRON-DEFICIENCY ANAEMIA

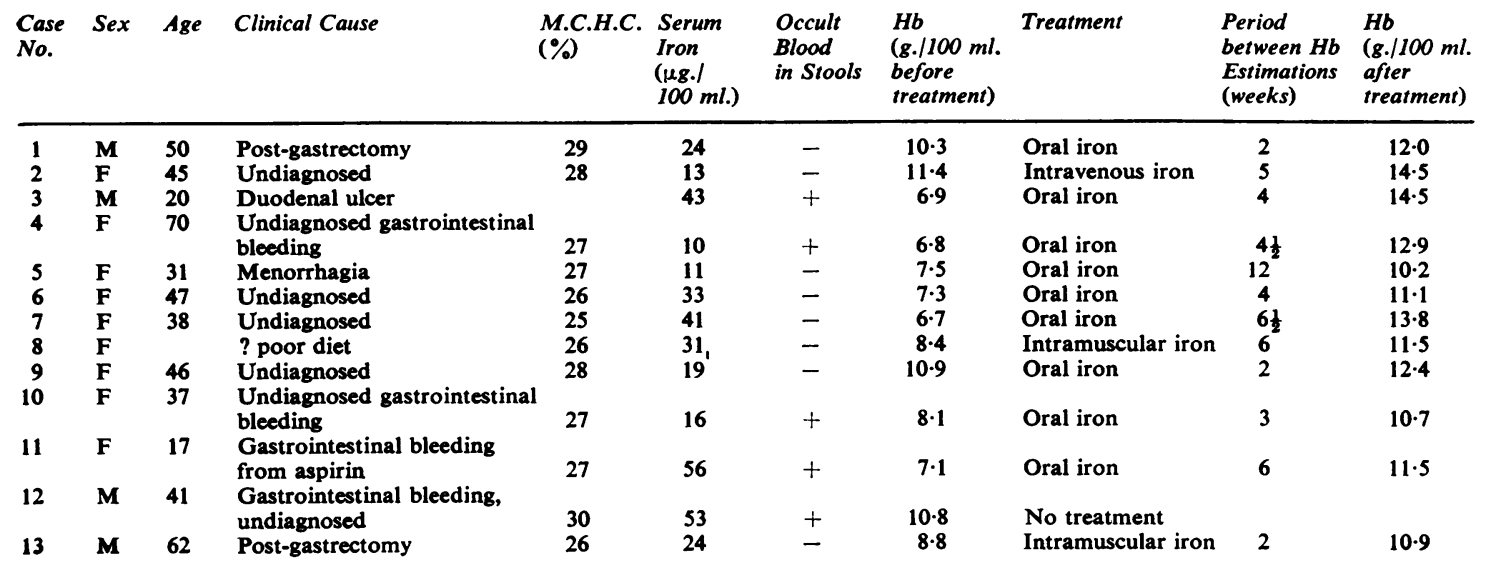

was studied in the circulation of 10 non-anaemic volunteer patients. The normal precautions for preventing the transmission of infection and for cross-matching were observed.

\section{RESULTS}

In three cases the life span of ${ }^{51} \mathrm{Cr}$-tagged irondeficient red cells was measured in the patients' own circulation; in three cases, both in the patients and in a normal volunteer; and in the remaining seven cases in normal volunteers only (Table II).

The $50 \%$ chromium survival time ( $\left.\mathrm{T} \frac{1}{2}\right)$ of tagged iron-deficient red cells in the patients' own circulation (Table II, column 1) varied between 25 and 30 days (with a mean of 26.8 days). The $\mathrm{T}^{\frac{1}{2}}{ }^{51} \mathrm{Cr}$ of the tagged iron-deficient cells in normal recipients was between 25 and 32 days (mean 28 days) (Table

TABLE II

LIFE SPAN OF ${ }^{51}$ CR-TAGGED IRON-DEFICIENT RED CELLS Case No. Apparent Half-time (days)

\begin{tabular}{ccc} 
& Patient to Patient & Patient to Recipient \\
\hline 1 & 30 & 26 \\
2 & 30 & 32 \\
3 & & 32 \\
4 & & $21^{1}$ \\
5 & & $17^{1}$ \\
6 & & 26 \\
7 & & 27 \\
8 & & 29 \\
9 & 25 & 25 \\
10 & 25 & 27 \\
11 & 26 & \\
12 & 25 & \\
13 & 25 to 30 & 25 to 32 \\
Range & 26.8 & 28 \\
Mean & &
\end{tabular}

${ }^{1}$ Results due to incompatibility and not included in the range or mean.
II, column 2), with two exceptions where the $T \frac{1}{2}$ ${ }^{51} \mathrm{Cr}$ was abnormally short. In these two instances the initial drop of ${ }^{51} \mathrm{Cr}$ activity was within the normal range (Figs. 1 and 2), and, when the slope of the initial drop was projected to cut the $50 \%$ line, the $\mathrm{T} \frac{1}{2}{ }^{51} \mathrm{Cr}$ was 23 and 28 days respectively. But at approximately 18 days the amount of radioactive chromium remaining in the blood decreased rapidly to reach background in 28 and 25 days respectively.

In one instance it was possible to repeat the survival, using the same recipient, 82 days after the first experiment (Fig. 3). The patient had had the iron deficiency corrected by this time and $\mathrm{Hb}$ was $15.2 \mathrm{~g} . / 100 \mathrm{ml}$. The $\mathrm{T}_{2}^{\frac{1}{2}}{ }^{51} \mathrm{Cr}$ was three days and all radioactivity had disappeared from the recipient's blood in 11 days.

Serological tests performed both before and after this cross-transfusion showed no demonstrable incompatibility between donor cells and recipient's serum. In addition, the recipient's serum was screened against a cell panel of known antigenic pattern, but no antibody could be detected.

ESTIMATION OF BLOOD IN FAECES Three autotransfused patients had occult blood in the stools. In only one of these could any significant amount of radioactivity be found in the faeces after the injection of the ${ }^{51} \mathrm{Cr}$ tagged red cells intravenously; the amount lost in this instance was estimated as $1.7 \mathrm{ml}$./day. This amount of blood loss would not alter the ${ }^{51} \mathrm{Cr}$ survival in the blood to any significant degree.

\section{DISCUSSION}

The results obtained in this investigation show that the life span of iron-deficient red cells in the circulation 


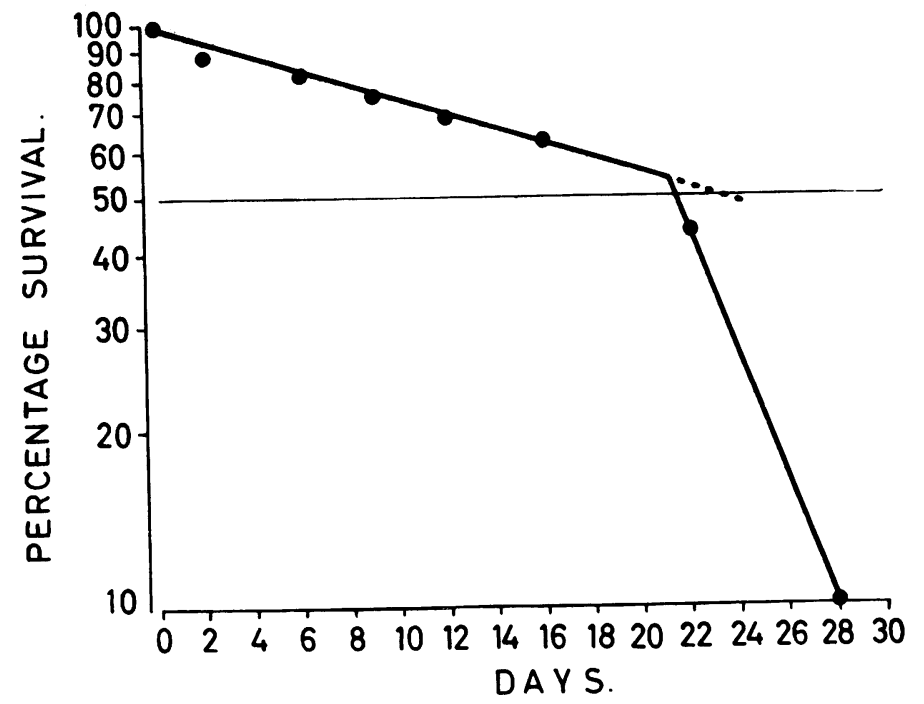

FIG. 1. The Cr survival, uncorrected for chromium elution, of red cells of patien No. 4 in a normal recipient on the firsp occasion. The continuous line represent乡 the actual findings, the interrupted line the projection of the slope of the origina? rate of destruction.

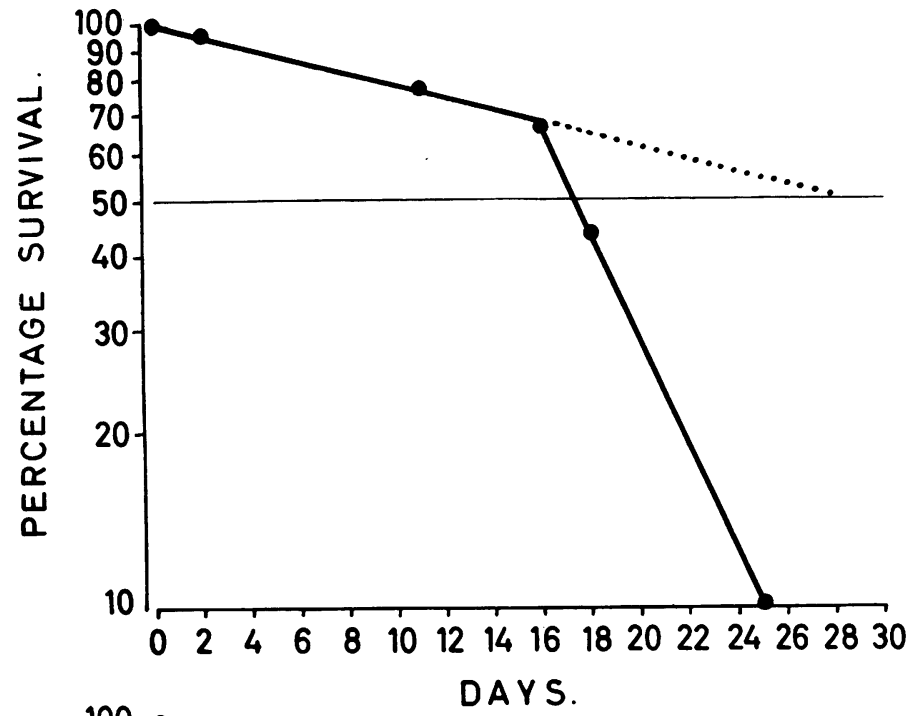

FIG. 2. The Cr survival, uncorrected for chromium elution, of red cells of patien No. 5 in a normal recipient. The con tinuous line represents the actual finding the interrupted line the projection of tht slope of the original rate of destruction

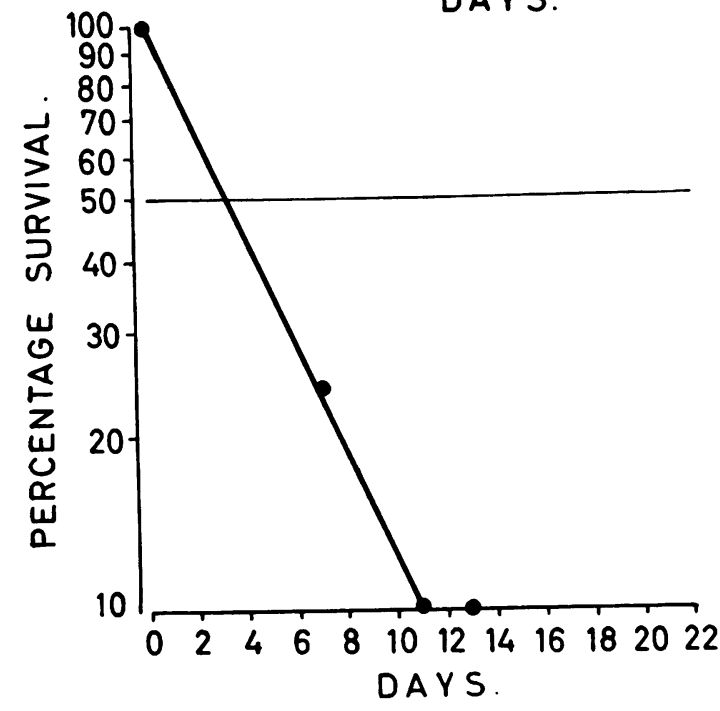

FIG. 3. The Cr survival, uncorrected for chromium elution of red cells of patient No. 4 in the same recipient, 82 days after the first transfusion of ${ }^{51} \mathrm{Cr}$-labelled erythrocytes (sie Fig. 1). 
is normal, both in the iron-deficient patient and in the normal circulation.

In the two instances where cross-transfusion resulted in an abnormally short survival in the recipient, the pattern of the survival suggested that incompatibility developed in the recipient to the donor's cells after transfusion and in one case a subsequent survival study showed that this was the most probable explanation.

Although no conventional tests could define this incompatibility, either before or after these studies, similar phenomena have been reported by Mollison (1959), Loutit, Mollison, and Young (1943), and Jandl and Greenberg (1957), and may be encountered in about $30 \%$ of cases where a small amount of homologous blood is transfused into normal recipients (Mollison, 1959).

From these studies, survival of red cells in irondeficiency anaemia would appear to be normal, but it has been shown that the plasma iron turnover in this anaemia is normal or increased (Bothwell, Callender, Mallett, and Witts, 1956). Pollycove (1959) deduced that in iron-deficiency anaemia where the mean red cell haemoglobin is reduced, this turnover must represent a daily haemoglobin production of above normal limits and, therefore, increased daily red cell production. If the survival of red cells in the peripheral blood is normal, then some red cells must be destroyed in the marrow before reaching maturity in the peripheral blood. This hypothesis of 'ineffective erythropoiesis' has been discussed by Witts (1961).

Our thanks are due to Professor L. J. Witts, Professor J. Chassar Moir, Professor J. A. Trueta, and Dr. E. F. Mason for permission to investigate their patients, and to Dr. M. M. Pickles for her advice and help relating to the serological aspects of this communication.

\section{REFERENCES}

Bothwell, T. H., Callender, S., Mallet, B., and Witts, L. J. (1956). Brit. J. Haemat., $2,1$.

—, and Mallett, B. (1955). Biochem. J., 59, 599.

Brown, G. M., Hayward, O. C., Powell, E. O., and Witts, L. J. (1944). J. Path. Bact., 56, 81.

Dacie, J. V. (1956). Practical Haematology, 2nd ed., p. 7. Churchill, London.

Jandl, J. H., and Greenberg, M. S. (1957). J. Lab. clin. Med., 49, 233

Kaplan, E., and Zuelzer, W. W. (1950). Ibid., 36, 517.

Loutit, J. F., Mollison, P. L., and Young, I. M. (1943). Quart. J. exp. Physiol., 3 , 183.

Mollison, P. L. (1959). Brit. med. J., 2, 1123.

Pollycove, M. (1959). In "Eisenstoffwechsel", ed. Keiderling, W., p. 20. Thieme, Stuttgart.

Ramsay, W. N. M. (1954). Biochem. J., 57, xvii.

Rasch, C. A., Cotton, E. K., Griggs, R. C., and Harris, J. W. (1958). J. Lab. clin. Med., 52, 938.

Veall, N., and Vetter, H. (1958). Radioactive Techniques in Clinical Research and Diagnosis, 1st ed., p. 227. Butterworth, London.

Verloop, M, C., Van der Wolk, M., and Heier, A. J. (1960). Blood, 15, 791.

Witts, L. J. (1961). Brit. med. J., 2, 325. 